\title{
Estimation of Genetic Variability, Heritability and Genetic Advance in Potato (Solanum tuberosum L.) Genotypes for Tuber Yield and Yield Related Traits
}

\author{
Awoke Ali Zeleke ${ }^{1, a, *}$, Tiegist Dejene Abebe ${ }^{2, b}$, Baye Berihun Getahun ${ }^{3, c}$ \\ ${ }^{1}$ Ethiopian Institute of Agricultural Research/Fogera National Rice Research and Training Center, 1937, Woreta, Ethiopia \\ ${ }^{2}$ College of Agriculture and Environmental Science, Bahir Dar University, 5501 Bahir Dar, Ethiopia \\ ${ }^{3}$ College of Agriculture and Environmental Science, Woldia University, 400 Woldia, Ethiopia
}

*Corresponding author

A R T I C L I N F O A B S T R A C T

Research Article

Potato is a high potential food security crop in Ethiopia. Genetic variability is the basis of all crop improvement programs. The study was conducted at Adet in 2018 with the objective of assessing the extent and pattern of genetic variability of potato genotypes for yield and yield related traits. A total of 36 potato genotypes were evaluated for 18 quantitative traits in simple lattice design. The

Received : 11/03/2021

Accepted : 03/09/2021 analysis of variance revealed that highly significant difference among the tested potato genotypes for all quantitative traits except stem number per hill. The phenotypic coefficient of variation was ranged from 4.56 to $56.01 \%$ (for specific gravity and unmarketable tuber yield ha ${ }^{-1}$ respectively) and the genotypic coefficient of variation was ranged from 2.32 to $40.66 \%$ (specific gravity and late blight severity percentage respectively). Days to attain $50 \%$ emergence, leaf area index, number of

Keywords:

Genotype

Heritability

Late blight

Potato

Trait marketable and total tubers per plant, marketable and total tuber yield ha ${ }^{-1}$, and late blight severity percentage showed high heritability and high genetic advance as percent of mean. Most of the traits had high phenotypic coefficient of variation and genotypic coefficient of variation; and coupled high heritability with high genetic advance as percent of mean. Traits having high heritability and high genetic advance as percent of means is effective for simple selection.

\section{Introduction}

Potato (Solanum tuberosum L.) is one of the most important food crops worldwide. It ranks third after rice and wheat in terms of human consumption (FAOSTAT, 2015). The total world potato production was $370,436,581$ metric tons (FAOSTAT, 2019). China was by far the largest producer, accounting for $24.8 \%$ of world production (FAOSTAT, 2019). In Ethiopia, during 2019/20 growing season more than 1 million small holders were engaged in potato production. The total area allocated for potato production has reached 70,362.22 ha, and total production is 924,728.361 tons in 2019 (CSA, 2019/20). Ethiopia ranked in $11^{\text {th }}$ in Africa and it covers $0.25 \%$ of the total world potato production (FAOSTAT, 2019). Currently potato is a high potential food security crop in Ethiopia due to its high yield potential, nutritional quality, short growing period and wider adaptability (Tewodros et al., 2014). On the other hand, the productivity of this crop in the country is very low (13.14 $\mathrm{t} \mathrm{ha}^{-1)}$ as compared to the world's average yield of 20.36 tons ha ${ }^{-1}$ (CSA, 2019/20 and FAOSTAT, 2019). The low yield is attributed to many factors, such as poor agronomic practices, lack of highquality and improved planting material, high cost of improved seed tubers, disease and pest problems (Gebremedhin et al., 2008; Tesfaye and Yigzaw, 2008).

The use of local tuber seeds and varieties with low genetic variability are the major cause of low high yield in potato. Breeders should take the challenge to provide food at cheaper rate to the millions of hungry people in developing countries by increasing the production of potato per unit area and per unit time. To initiate any breeding program to this direction, presence of enough genetic variability in the population for yield and yield related traits should be considered as pre requisite element. Moreover, application of perfect breeding method is dependent on estimation of genetic gain of the characters for successful selection as to develop desirable traits suggested (Johnson et al., 1955). Genetic variability is the basis of all crop improvement programs. Sufficient genetic variability, if present, can be exploited for developing superior cultivar or varieties. The total variability can be 
partitioned into heritable and non-heritable components with the help of genetic parameters like genotypic and phenotypic coefficients of variation, heritability and genetic advance. Parameters of genotypic and phenotypic coefficients of variation (GCV and PCV) are useful in detecting the amount of variability present in the available genotypes. Heritability and genetic advance help in determining the influence of environment expression of the characters and the extent to which improvement is possible after selection (Robinson et al., 1949). High heritability alone is not enough to make efficient selection in segregating generation, unless the information is accompanied for substantial amount of genetic advance (Johnson et al., 1995). Knowledge on the nature of variability and association of yield with its components is of great impotence for identification of superior parents in any breeding program (Rahman, 2015).

In Ethiopia, potato breeding method depends on a conventional breeding method such as introduction of potato germplams from International Potato Center (CIP) every year. Thus indicated that introduced genotypes needs to be characterized and evaluated, because quantitative traits are strongly influenced by environmental factors. Knowing the nature of genetic variability and diversity of genotypes is essential to use as a base material for further breeding program and to meet the diversified goals of plant breeding such as for increasing tuber yield, wider adaptation, desirable quality, pest and disease resistance. Therefore, the objective of the present study is to assess the extent and pattern of genetic variability of potato genotypes for agronomic, yield, and tuber quality traits.

\section{Materials and Methods}

\section{Description of the Study Area}

The experiment was conducted at Adet Agricultural Research Center's experimental station in Northwestern Ethiopia. It is nearly $450 \mathrm{~km}$ away from Addis Ababa and
$42 \mathrm{~km}$ from the Capital City of Amhara Regional State Bahir Dar. Geographically, it is located at $11^{\circ} 16^{\prime} \mathrm{N}$ latitude and $37^{\circ} 29^{\prime} \mathrm{E}$ longitude at an altitude of 2240 meter above sea level. The mean annual rain fall is $869 \mathrm{~mm}$ and the mean annual temperature is $18.56^{\circ} \mathrm{C}$ (National Meteorological Agency Bahir Dar Branch, 2018). The soil type of the study area is Nitosol soil.

\section{Experimental Design, Treatments and Procedures}

A total of 36 potato genotypes, consisting of 33 advanced genotypes introduced from International Potato Center (CIP) and three recently released potato varieties as standard checks, were used (Table 1). All of the 36 genotypes were planted at Adet Agricultural Research Center on station during the main rainy cropping season and planting on 25 June 2018 and harvesting on 19 October 2018. The genotypes arranged in simple lattice design with two replications and each gross plot were $3 \mathrm{~m} \times 3 \mathrm{~m}=9 \mathrm{~m}^{2}$ consisting of four rows, which accommodated 10 plants per row and thus 40 plants per plot. The net plot size is 1.5 $\mathrm{m} \times 2.4 \mathrm{~m}=3.6 \mathrm{~m}^{2}$. The spacing between rows and plants were $0.75 \mathrm{~m}$ and $0.30 \mathrm{~m}$, respectively. The spacing between plots and adjacent replications were $1 \mathrm{~m}$ and 1.5 $\mathrm{m}$, respectively. The experimental field was cultivated to a depth of $25-30 \mathrm{~cm}$ by a tractor and ridges were made manually after leveling. Fertilizer application was made as per the specific recommendation for the location, in which NPS as a source of phosphorus was applied at a rate of 180 $\mathrm{kg} / \mathrm{ha}$ and Urea as a source of nitrogen was applied at rate of $117 \mathrm{~kg} / \mathrm{ha}$. NPS was applied once during planting in the rows, while urea was applied in split application half at emergence and half at $50 \%$ flowering as a side dress application (Adet Agricultural Research Center, 2018). All other agronomic practices such as weeding, cultivation and spraying Redomil chemical were kept uniform for all treatments in each plot. The two middle rows were used for data collection.

Table 1. List of potato genotypes and accession code used for experimentation at Adet, 2018

\begin{tabular}{c|ccc}
\hline No. & Accession code & No. & Accession code \\
\hline 1 & CIP-308517.501 & 19 & CIP-308511.507 \\
2 & CIP-308527.501 & 20 & CIP-308499.001 \\
3 & CIP-308510.03 & 21 & CIP-308482.506 \\
4 & CIP-308985.01 & 22 & CIP-308522.502 \\
5 & CIP-308526.502 & 23 & CIP-308518.001 \\
6 & CIP-3038522.504 & 24 & CIP-308487.500 \\
7 & CIP-308517.500 & 25 & CIP-308516.500 \\
8 & CIP-308526.501 & 26 & CIP-308532.500 \\
9 & CIP-308499.502 & 27 & CIP-308522.500 \\
10 & CIP-308530.501 & 28 & CIP-308530.501 \\
11 & CIP-308525.01 & 29 & CIP-308523.500 \\
12 & CIP-308500.01 & CIP-308482.504 \\
13 & CIP-308522.503 & 30 & CIP-308516.501 \\
14 & CIP-308527.502 & 31 & CIP-308482.505 \\
15 & CIP-395077.120 & 32 & Gudanie (CIP-386423.13) \\
16 & CIP-308511.508 & 33 & Belete (CIP-393371.58) \\
17 & CIP-308522.501 & 34 & Dagim (CIP-396004.337) \\
\hline
\end{tabular}

Note: All genotypes were introduced from CIP (International Potato Center) \& the released varieties were from Adet Agricultural Research Center 


\section{Data Collection}

Phenological, growth, tuber yields and yield-related data was collected as follows:

Days to 50\% emergence: - the numbers of days from planting to the emergence of $50 \%$ of plants in each plot was recorded.

Days to $50 \%$ flowering: - was recorded as actual number of days taken from emergence to the days at which $50 \%$ of the plants in each plot produced flowers.

Days to maturity: - was recorded by counting days from emergence to days on which more than $90 \%$ of the plant in each plot get yellow.

Plant height in $\mathrm{cm}$ : - The height of five plants in each plot was measured in centimeter from the ground surface to the tip of the main stem and averaged to get the mean plant height.

Number of stem per plant: - It was recorded as the average stem count of five hills or plant per plot at $50 \%$ flowering. Only stems that were emerged independently above the soil as single stems were considered as main stems.

Leaf area index (LAI):- To determine leaf area index, five plants (hills) were used from each plot. Individual leaf area of the potato plants was estimated from individual leaf length by using the formula developed Firman and Allen (1989) and leaf area index were determined by dividing the total leaf area of a plant by the ground area covered by a plant.

Log $10\left(\right.$ leaf area in $\left.\mathrm{cm}^{2}\right)=2.06 \times \log 10($ leaf length in cm) -0.458

Number of marketable tubers per plant: - Number of tubers harvested from five plants (hills) which counted as marketable after sorting tubers which have greater or equal to $20 \mathrm{~g}$ weight, free from disease and insect attack. The average number of marketable tubers were counted and registered.

Number of unmarketable tubers per plant: - The tubers that are sorted as diseased, insect attacked and small-sized $(<20 \mathrm{~g})$ from five plants as indicated in the above were recorded as unmarketable tuber number. The average number of unmarketable tubers were counted and registered.

Total tuber number per hill: - the total number of tubers produced per plant was recorded or it was recorded by the sum of both marketable and unmarketable tubers number per plant.

Average tuber weight ( $g /$ tuber):- It was determined by dividing the total fresh tuber weight to the respective total tubers number which was harvested from five plants (hills).

Marketable tuber yield $\left(t h a^{-1}\right)$ :- The total tuber weight which were free from diseases, insect pests, and greater than or equal to $20 \mathrm{~g}$ in weight determined from the net plot area and were converted to tons per hectare.

Unmarketable tuber yield $\left(t h a^{-1}\right)$ :- was determined by weighting tubers that were sorted out as diseased, insect attack and small-sized $(<20 \mathrm{~g})$ from the net plot area and converted to tons per hectare.

Total tuber yield $\left(t h a^{-1}\right)$ : This was determined as the sum of the weights of marketable and unmarketable tubers from the net plot area and converted to tons per hectare.

Tuber quality attributes was calculated as follows:

Tuber dry matter content (TDMC) (\%): Five fresh tubers were randomly taken from each plot, washed, weighed and sliced at harvest, dried for seven days under sun and finally in oven at $75^{\circ} \mathrm{C}$ for 72 hours until a constant weight attained and dry matter percent calculated according to (William and Woodbury, 1968).

$$
\text { Dry matter }=\frac{\text { weight of sample after drying }(\mathrm{g})}{\text { initial fresh weight of sample }(\mathrm{g})} \times 100
$$

Specific gravity of tubers ( $S G$ ): SG was determined by the weight in air and in water method. Five $\mathrm{kg}$ tuber of all shapes and sizes were randomly taken from each plot. The tubers were washed with water. Then after the sample were first weighed in air and then re-weighed suspended in water. Specific gravity was calculated according to (Kleinkopf et al., 1987) formula.

$$
\text { Specific gravity }=\frac{\text { Weight in air }}{\text { Weight in air-Weight in water }}
$$

Starch (\%): The percentage of starch was calculated from the specific gravity as follows:

Starch $(\%)=17.546+199.07 \times($ SG-1.0988) (Talburt and Smith, 1959). Specific gravity (SG) was determined as indicated above by the weight in air and weight in water method.

Total soluble solids $\left({ }^{\circ}\right.$ Brix $)$ : The Brix of the raw potato samples was determined using a method as described by Pardo et al. (2000) using hand refractometer. The Brix was measured in the juice obtained after washing, crushing and extracting juice of the tuber samples.

Disease Data: Assessment of severity of late blight under field conditions in percent was recorded on a plot basis taking into account the number of plants developing disease symptoms in a leaf and/or many leaves and plants free from disease following the procedures of Henfling (1987).

\section{Statistical Data Analysis}

Analysis of Variance

The collected data were subjected to analysis of variance (ANOVA) for Simple Lattice by SAS computer software (9.0). Duncan Multiple Range Test (DMRT) was used to compare means at $5 \%$ and $1 \%$ level of significance.

Phenotypic and genotypic variances

The phenotypic and genotypic variability of each quantitative trait was estimated as genotypic and phenotypic variance components and coefficient of variation. The phenotypic and genotypic variances were estimated according to the method suggested by Singh and Chaudhary (1985) as follows:

$$
\text { Genotypic variance }\left(\sigma^{2} g\right)=\frac{\text { Msg-Mse }}{r}
$$

Where: $\sigma^{2} \mathrm{~g}=$ genotypic variance, $\mathrm{MSg}=$ mean square due to genotype, MSe = environmental variance (mean of square) and $r=$ number of replications

Phenotypic variance $\left(\sigma^{2} \mathrm{p}\right)=\sigma^{2} \mathrm{~g}+\sigma^{2} \mathrm{e}$

Where: $\sigma^{2} \mathrm{p}=$ phenotypic variance, $\sigma^{2} \mathrm{~g}=$ genotypic variance, $\sigma^{2} \mathrm{e}=$ environmental variance

Environmental variance $\left(\sigma^{2} \mathrm{e}\right)=\mathrm{MSe}$

where: $\mathrm{MSe}=$ error mean square 
Coefficient of variation at phenotypic, genotypic and environmental levels was estimated by using the formula, adopted by Burton and De vane (1953) as follows:

Genotypic Coefficient of Variation $(\mathrm{GCV})=\frac{(\sqrt{\boldsymbol{\sigma 2 g})}}{\overline{\mathbf{x}}} \times 100$

Phenotypic Coefficient of Variation $(\mathrm{PCV})=\frac{(\sqrt{\boldsymbol{\sigma 2 p}})}{\overline{\mathbf{x}}} \times 100$

Where: $P C V=$ Phenotypic coefficient of variation, $\mathrm{GCV}=$ Genotypic coefficient of variation, $\overline{\mathrm{x}}=$ population mean of the character being evaluated. PCV and GCV values were categorized as low $(0-10 \%)$, moderate (10$20 \%$ ), and high (>20\%) as suggested by Sivasubramaniah and Menon (1973).

Broad Sense Heritability $\left(H^{2} b\right)$

Broad sense heritability was estimated based on the formula given by Allard (1960) and Falconer and Mackay (1996) as follows: as follows:

$$
\text { Heritability in broad sense } \mathrm{H}^{2} \mathrm{~b}=\frac{\sigma 2 \mathrm{~g}}{\sigma 2 \mathrm{p}} \times 100
$$

Where: $H^{2} b=$ Heritability in broad sense, $\sigma^{2} p=$ phenotypic variance, $\sigma^{2} \mathrm{~g}=$ genotypic variance. According to Singh (2001), heritability values regarded as low (0$40 \%$ ), medium (40-59\%) moderately high (60-79\%) and very high ( $80 \%$ and above)

Estimation of genetic advance and genetic advance as percent of mean

Genetic advance and genetic advance as percent of means were estimated as described by (Allard, 1960) and Johnson et al. (1955) as:

Genetic Advance $(\mathrm{GA})=\mathrm{K} \sigma \mathrm{p} \mathrm{H}_{\mathrm{b}}^{2}$
Where: $\mathrm{K}=$ the standardized selection differential at 5 $\%$ (2.063), $\sigma \mathrm{p}=$ phenotypic standard deviation and, $\mathrm{H}^{2} \mathrm{~b}=$ heritability in broad sense

Genetic advance as percent of mean $(\mathrm{GAM})=\frac{G A}{\overline{\mathrm{x}}} \times 100$

Where: GA $=$ genetic advance, and $\overline{\mathrm{x}}=$ mean of population

The GA as percent of mean was categorized as low (0$10 \%)$, moderate $(10-20 \%)$ and high $(>20 \%)$ as suggested by Johnson et al. (1955).

\section{Results and Discussions}

Analysis of variance

The result of analysis of variance showed that there is highly significant $(\mathrm{P} \leq 0.001)$ difference among the tested potato genotypes for all traits except stem number per hill (Table 2). The findings on variance for tuber yield and its components indicates the existence of substantial amount of variability for most of the traits in experimental material studied. This provides an opportunity for a breeder to select best genotypes for their better tuber yield and other yield related traits. Many authors also reported the existence of significant variation among potato genotypes for different traits. Addisu et al. (2013) reported that, highly significant difference among potato genotypes with respect to days to emergence, days to flowering, days to maturity, plant height, number of stem per plant, tuber number per plant and tuber yield $(\mathrm{kg})$ per plant. Similarly, highly significant difference for plant height, leaf area index, average tuber number per plant, average tuber weight (g/tuber), dry matter content $(\%)$ and total tuber yield $(\mathrm{t} / \mathrm{ha})$ reported by Rahman, (2015), Getachew et al. (2016), and Ebrahim et al. (2018).

Table 2. Analysis of variance for 18 traits at Adet Agricultural Research center in 2018/19 cropping season in Simple Lattice Design

\begin{tabular}{|c|c|c|c|c|c|c|c|}
\hline \multirow{3}{*}{ Traits } & \multirow{3}{*}{ Mean } & Rep & Genotype & Error & \multirow{3}{*}{$\mathrm{CV}$} & \multirow{3}{*}{$\mathrm{R}^{2}$} & \multirow{3}{*}{ LSD } \\
\hline & & \multicolumn{3}{|c|}{ DFF } & & & \\
\hline & & (1) & $(35)$ & (35) & & & \\
\hline$\overline{\mathrm{DE}}$ & 15.74 & 0.68 & $13.56 * *$ & 0.42 & 4.12 & 0.98 & 1.34 \\
\hline DF & 48.13 & 3.13 & $11.48^{* *}$ & 1.43 & 2.48 & 0.93 & 2.46 \\
\hline DM & 93.46 & 23.4 & $48.74 * *$ & 1.89 & 1.47 & 0.98 & 2.83 \\
\hline NS & 5.12 & 3.92 & $2.3 \mathrm{~ns}$ & 1.66 & 25.15 & 0.74 & 2.67 \\
\hline $\mathrm{PH}$ & 66.84 & 83.2 & $131 * *$ & 2.24 & 7.3 & 0.85 & 10.32 \\
\hline LAI & 3.76 & 2.68 & $0.97 * *$ & 0.14 & 10.12 & 0.88 & 0.82 \\
\hline NMTPP & 8.70 & 11.14 & $16.98 * *$ & 2.66 & 18.84 & 0.87 & 3.18 \\
\hline NUMTPP & 2.90 & 0.80 & $2.2 *$ & 1.05 & 35.78 & 0.68 & 2.07 \\
\hline TTNPP & 11.6 & 17.91 & $13.81 * *$ & 2.24 & 13 & 0.91 & 3.09 \\
\hline ATW & 78.13 & 926.08 & $618.4 * *$ & 179.26 & 17.14 & 0.78 & 27.3 \\
\hline MTY & 29.28 & 0.13 & $195.1 * *$ & 13.02 & 12.32 & 0.94 & 6.97 \\
\hline UMTY & 3.08 & 0.36 & $4.36^{* *}$ & 1.63 & 41.2 & 0.73 & 2.66 \\
\hline TTY & 32.36 & 0.05 & $206.7 * *$ & 12.30 & 10.81 & 0.94 & 6.95 \\
\hline DMC & 23.03 & 2.12 & $14.89 *$ & 6.98 & 11.47 & 0.68 & 5.78 \\
\hline SG & 1.14 & 0.0058 & $0.0034 *$ & 0.00185 & 3.77 & 0.66 & 0.09 \\
\hline STA & 28.88 & 134.4 & $130.3 * *$ & 38.68 & 21.53 & 0.78 & 12.51 \\
\hline TSS & 3.91 & 6.69 & $0.84 * *$ & 0.30 & 13.97 & 0.77 & 1.26 \\
\hline LB & 59.58 & 50.0 & $1191.8 * *$ & 17.86 & 7.09 & 0.98 & 8.49 \\
\hline
\end{tabular}

Note: DFF-Degree of freedom, DE- Days to 50\% emergence, DF- days to 50\% flowering, DM- days to maturity, PH - plant height in cm, NS-number of stems per hill, LAI- leaf area index, NMTPP- number of marketable tubers per plant, NUMTPP- number of unmarketable tubers per plant, TNTPPtotal number of tubers per plant, ATW-average tuber weight (g/tuber), MTY-marketable tuber yield (t/ha), UMTY-unmarketable tuber yield (t/ha), TTY total tuber yield (t/ha), DMC- dry matter content (\%), SG-specific gravity, STA starch percentage (g/100g), TSS- total soluble solid $\left({ }^{0}\right.$ brix), LB-late blight severity percentage $(\%), \mathrm{CV}$ - coefficient of variation, $\mathrm{R}^{2}$ - coefficient of determination. 


\section{Estimates of Variance Components}

The variability components (genotypic and phenotypic variance and coefficient of variations, heritability in broad sense and genetic advance as percent of mean) were estimated for seventeen traits and results are presented below in Table 3. However, the results excluded the one trait (number of stems per hill) because of absence of significant difference at both $1 \%$ and $5 \%$ level of significant.

\section{Phenotypic and genotypic coefficient of variation}

The result of analysis of phenotypic coefficient of variation $(\mathrm{PCV})$ was relatively greater than the genotypic coefficient of variation (GCV) for all traits. It is due to presence of substantial influence of environmental factors besides the genetic variation for expression of these traits. The phenotypic coefficient of variation (PCV) and genotypic coefficient of variation (GCV) values can be categorized as low $(<10 \%)$, moderate $(10-20 \%)$, and high (>20\%) according to Sivasubramaniah and Menon (1973). Based on these categories most of the traits such as number of marketable tubers per plant (36.19 and 30.90\%), number of unmarketable tubers per plant (44.57 and $26.51 \%)$, total number of tubers per plant (24.59 and $20.87 \%$ ), marketable tuber yield $\mathrm{t} \mathrm{ha}^{-1}$ (34.84 and 32.59\%), unmarketable tuber yield $\mathrm{t}^{-1}$ (56.01 and $\left.37.81 \%\right)$, total tuber yield $\mathrm{t}$ ha ${ }^{-1}$ (32.26 and $30.40 \%)$, starch percentage (31.83 and $23.44 \%$ ) and late blight severity percentage (41.28 and $40.66 \%$ ) had high PCV and GCV (>20\%), respectively. However, days to attain $50 \%$ flowering (5.28 and $4.66 \%$ ), days to maturity (5.38 and $5.18 \%)$ and specific gravity (4.56 and $2.32 \%$ ) showed low PCV and GCV $(<10 \%)$ respectively. Moderate PCV and GCV (10-20\%) was observed in days to attain $50 \%$ emergence (16.80 to 16.28 ), plant height 3.16 to $10.96 \%)$, leaf area index $(19.81$ to $17.13 \%)$ and total soluble solid (19.26 to 13.26). The highest magnitude of PCV and GCV was observed for unmarketable tuber yield per hectare (56.01 and 37.81\%) while the lowest PCV and GCV were observed in specific gravity (4.56 and 2.32\%) respectively. Average tuber weight (g/tuber) had high PCV $(25.56 \%)$ and moderate GCV $(18.97 \%)$. Moderate PCV $(14.6 \%)$ and low GVC (8.64\%) was observed in dry matter content percentage (Table 3 ). In agreement with this result, high PCV and GCV for tuber yield per plant, hectare, number of tuber per plant has been reported by Rahman (2015), Hajam et al. (2018), and Mishra et al. (2017).

Similarly, Getachew et al. (2016) also reported low PCV and GCV for days to maturity (7.6 and 7.2\%) and high PVC and GCV for marketable tuber number per hill (53.3 and $44.8 \%$ ), marketable yield t/ha (51.2 and 47.2\%) and total tuber yield t/ha (56.2 and 51.9\%). Higher PCV and GCV value (45.67 and $43.57 \%$ respectively) for late blight severity percentage was reported by Wasu (2014).

Estimate of broad sense heritability and genetic advance

The estimated broad sense heritability and genetic advance for 17 quantitative traits were presented in Table 3. The heritability values ranged from $25.93 \%$ (specific gravity) to $97.05 \%$ (late blight severity percentage), and genetic advance values ranged from $0.03 \%$ (specific gravity) to $49.24 \%$ (late blight severity percentage). The heritability was categorized as low (0 - 40\%), medium (40 - 59\%), moderately high (60-79\%) and very high (> 80\%) as suggested by Singh (2001). Based on these categories traits such as days to attain $50 \%$ emergence, days to maturity, marketable tuber yield $\mathrm{t} \mathrm{ha}^{-1}$, total tuber yield $\mathrm{t}$ ha $^{-1}$ and late blight severity percentage showed very high heritability $(>80)$. The highest heritability was recorded $(97.05 \%)$ for late blight severity percentage followed by days to attain $50 \%$ emergence $(93.96 \%)$ and days to maturity (92.57\%) (Table 3). Simple selection for traits having high heritability would be very effective as it would be a close correspondence between genotype and phenotype. In accordance with this result, high heritability for marketable tuber yield and total tuber yield has been reported in previous studies (Rahman, 2015; Mishra et al., 2017; Panigrahi et al., 2017; Hajam et al., 2018). Similarly, higher heritability for late blight severity percentage (91.02\%) was reported by (Wasu, 2014).

The genetic advance as percent mean (GAM) was categorized as low $(0-10 \%)$, moderate $(10-20 \%)$ and high $(>20 \%)$ as suggested by Johnson et al. (1955). Accordingly, most of the traits showed high GAM (>20\%). However, days to maturity $(10.28 \%)$ and dry matter content $(10.71 \%)$, total soluble solid $(18.82 \%)$ and plant height (18.83) had moderate GA (10-20\%). High genetic advance was obtained from late blight percentage $(82.64 \%)$ and low genetic advance was obtained in specific gravity $(2.44 \%)$ followed by days to attain $50 \%$ flowering $(8.48 \%)$ (Table 3$)$. In agreement with this result, the highest GAM was recorded for marketable tuber yield and total tuber yield has been reported by Rahman (2015) and Mishra et al. (2017). A higher genetic advance as percent of mean for late blight intensity and severity percentage (96.31 and 85.63 respectively) was reported by Wasu (2014). Medium GAM for plant height, dry matter content percentage was reported by Rahman (2015). Most of the traits coupled medium to very high heritability with high genetic advance except specific gravity and dry matter content percentage coupled with low heritability and low to medium genetic advance respectively (Table 3 ). Traits with high heritability couple with high GAM indicated additive gene action for the expression these traits and effective for simple selection while traits with low heritability couple with low GAM indicated non-additive gene action for the expression of these traits.

Panigrahi et al. (2017) reported high heritability coupled with high genetic advance in total tuber yield and marketable tuber yield was found indicating the influence of additive gene effect on these characters. High heritability coupled with high genetic advance for marketable tuber yield and total tuber yield was reported by previous studies (Rahman, 2015; Mishra et al., 2017; Panigrahi et al., 2017; Hajam et al., 2018). Similarly, high heritability coupled with high GAM for leaf area index and number of tuber per plant was reported by Rahman (2015), and Hajam et al. (2018).

\section{Conclusions}

The tested potato genotypes in the current study area showed statistically high significant difference at $\mathrm{P} \leq 0.001$ level of significance revealing presence of a substantial amount of genetic variability. It confirms a positive response for the effectiveness of selection based on the traits with high and medium PCV and GCV values for trait of interest improvement. 
Table 3. Estimate of variability components for 17 traits in 36 potato genotypes evaluated at Adet Agricultural Research Center in 2018/19 cropping season

\begin{tabular}{l|cccccccc}
\hline \multicolumn{1}{c|}{ Traits } & $\sigma^{2} \mathrm{~g}$ & $\sigma^{2} \mathrm{p}$ & $\sigma^{2} \mathrm{e}$ & $\mathrm{PCV}(\%)$ & $\mathrm{GCV}(\%)$ & $\mathrm{H}^{2} \mathrm{~b}(\%)$ & $\mathrm{GA}$ & $\mathrm{GAM}(\%)$ \\
\hline DE & 6.57 & 6.99 & 0.42 & 16.80 & 16.28 & 93.99 & 5.13 & 32.57 \\
DF & 5.03 & 6.46 & 1.43 & 5.28 & 4.66 & 77.85 & 4.08 & 8.48 \\
DM & 23.43 & 25.31 & 1.88 & 5.38 & 5.18 & 92.57 & 9.61 & 10.28 \\
PH & 53.66 & 77.33 & 23.67 & 13.16 & 10.96 & 69.39 & 12.59 & 18.83 \\
LAI & 0.42 & 0.56 & 0.14 & 19.81 & 17.13 & 74.77 & 1.15 & 30.56 \\
NMTPP & 7.16 & 9.82 & 2.66 & 36.19 & 30.90 & 72.91 & 4.71 & 54.43 \\
NUMTPP & 0.58 & 1.63 & 1.05 & 44.57 & 26.51 & 35.38 & 0.93 & 32.54 \\
TTNPP & 5.78 & 8.03 & 2.24 & 24.59 & 20.87 & 72.04 & 4.21 & 36.55 \\
ATW & 219.57 & 398.83 & 179.26 & 25.56 & 18.97 & 55.05 & 22.68 & 29.03 \\
MTY & 91.04 & 104.06 & 13.02 & 34.84 & 32.59 & 87.49 & 18.41 & 62.88 \\
UMTY & 1.37 & 3.00 & 1.63 & 56.01 & 37.81 & 45.58 & 1.63 & 52.66 \\
TTY & 97.18 & 109.48 & 12.30 & 32.26 & 30.40 & 88.76 & 19.16 & 59.08 \\
DMC & 3.96 & 10.94 & 6.98 & 14.36 & 8.64 & 36.17 & 2.47 & 10.71 \\
SG & 0.001 & 0.003 & 0.002 & 4.56 & 2.32 & 25.93 & 0.03 & 2.44 \\
STA & 45.83 & 84.51 & 38.68 & 31.83 & 23.44 & 54.23 & 10.28 & 35.61 \\
TSS & 0.27 & 0.57 & 0.30 & 19.26 & 13.26 & 47.37 & 0.74 & 18.82 \\
LB & 586.96 & 604.82 & 17.86 & 41.28 & 40.66 & 97.05 & 49.24 & 82.64 \\
\hline
\end{tabular}

Note: DE- Days to 50\% emergence, DF- days to 50\% flowering, DM- days to maturity, PH -plant height in cm, NS-number of stem per hill, LAI- leaf area index, NMTPP- number of marketable tubers plant, NUMTPP- number of unmarketable tubers plant, TTNPP- total number tubers per plant, ATW-average tuber weight (g/tuber), MTY-marketable tuber yield (t/ha), UMTY-unmarketable tuber yield (t/ha), TTY total tuber yield (t/ha), DMCdry matter content $(\%)$, SG-specific gravity, STA starch percentage (g/100g), TSS- total soluble solid $\left({ }^{0}\right.$ brix $)$, LB-late blight severity percentage $(\%)$, $\sigma^{2} \mathrm{~g}=$ genotypic variance, $\sigma^{2} \mathrm{p}=$ phenotypic variance, $\sigma^{2} \mathrm{e}$ - environmental variance, $\mathrm{GCV}=$ genotypic coefficient of variation in percent, $\mathrm{PCV}=$ phenotypic coefficient of variation in percent, $\mathrm{H}_{\mathrm{b}}{ }_{\mathrm{b}}=$ heritability in broad sense, $\mathrm{GA}=$ expected genetic advance at $5 \%$ selection intensity, $\mathrm{GAM} .=$ genetic advance as percent mean.

Most of the traits had high PCV and GCV; and coupled high heritability with high GAM. Traits with high heritability coupled with high genetic advance as percent of means indicated that additive gene action for the expression the traits and effective for simple selection.

\section{Acknowledgment}

The first author acknowledges Adet Agricultural Research Center for giving the tested potato genotypes and supported in the field from planting to harvesting period. The authors also would like to express their special gratitude and warm appreciation to Ethiopian Institute of Agricultural Research (EIAR) for fully financing the study.

\section{References}

Addisu F, Yohannes P, Habtamu Z. 2013. Genetic variability and association between agronomic characters in some potato (Solanum tuberosum L.) genotypes in SNNPRS, Ethiopia. International Journal of Biodiversity and Conservation, 5(8): 523-528.

Adet Agricultural Research Center. 2018. Fertilizer recommendations for potato production.

Allard RW. 1960. Principles of Plant Breeding. John Wiley and Sons Inc, New York, p .485.

Burton WG, De vane EH. 1953. Estimation of heritability in Tall Festuca (Fesuca arundinacea) from replicated clonal material. Agronomy Journal, (45):478-481.

CSA, 2019/20. Agricultural Sample Survey Report on Area and Production (Private Peasant Holdings Meher Season. Central Statistical Agency of Ethiopia, Statistical Bulletin. Addis Ababa, Ethiopia.

Ebrahim S, Wasu M. Tesfaye A. 2018. Genetic Variability in Potato (Solanum tuberosum L. Genotypes for Tuber Quality, Yield and Yield Related Traits at Holetta, Central Highlands of Ethiopia. (MSc.Thesis, Haramaya University).
Ethiopia National Metrological Agency, Bahir Dar Branch. 2018. Annual Methrological data of Adet Agricultual Research Center.

Falconer DS, Mackay FC. 1996. Introduction to Quantitative Genetics and environmental variability in Soya bean. Agronomy Journal, (47): 314-318.

FAOSTAT, 2015. Data base of agricultural production [online]. Available at http://faostat3.fao.org/home/E (updated 31 September 2015; accessed 11 October 2015). Food and Agriculture Organization, Rome, Italy.

FAOSTAT, 2019. Countries - Select All; Regions - World + (Total); Elements - Production Quantity; Items - Potatoes; Years - 2017.

Firman DM, Allen EJ. 1989. Relationship between light interception, ground cover and leaf area index in potatoes. The Journal of Agricultural Science, 113(03), pp.355-359.

Gebremedhin W, Endale G, Berga L. 2008. Potato variety development. Pp. 15-32. In : Gebremedhin Woldegiorgis, Endale Gebre and Berga Lemaga (eds.), Root and Tuber Crops: The Untapped Resources. Ethiopian Institute of Agricultural Research, Ethiopia. Addis Ababa, Ethiopia

Getachew A, Wassu M, Tesfaye A. 2016. Genetic variability studies in potato (Solanum tuberosum L.) genotypes in Bale highlands, South Eastern Ethiopia. Journal of Biology, Agriculture and Healthcare, 6(3): 117- 119.

Hajam MA, Bhat TA, Rather AM, Khan SH, Reyaz L, Shah MA, Paul S. 2018. Genetic variability, heritability and genetic advance for various qualitative characters of potato. IJCS, 6(6), pp.518-522.

Heinfnings JW.1987. Late blight of potato (Phytophthora infestans) Technical information. Lima,Peru, Bulletin 4,22 pp.

Johnson HW, Robinson HF, Comstock RE.,1995. Genotypic and phenotypic correlations in soybeans and their implications in selection. Agronomy journal, 47(10), pp.477-483.

Johnson HW. Robinson HF, Comstock RE. 1955. Estimates of genetic and environmental variability in soybeans. Agronomy Journal, 47(7): 314-318. 
Kleinkopf GE, Westermann DT, Wille MJ, Kleinschmidt GD. 1987. Specific gravity of Russet Burbank potatoes. American potato journal, 64(11), pp.579-587.

Mishra S, Singh J, Sharma PK. 2017. Studies on Parameters of Genetic Variability for Yield and its Attributing Traits in Potato (Solanum tuberosum L.). Biosciences Biotechnology Research Asia,14(1), pp.489-495.

Panigrahi KK, Pradhan J, Panigrahi P, Sarkar KK. 2017. Genetic Variability, Character Association and Path Coefficient Analysis of Yield Attributes for Medium and Late Maturing Potato Cultivars. International Journal of Current Microbiology and Applied Sciences, 6 (7), pp.2558-2566.

Pardo JE, Alvarruiz A, Perez JI, Gomez R, Varon R. 2000. Physical-chemical and sensory quality evaluation of potato varieties (Solanum tuberosum L.). Journal of Food Quality, 23 (2), pp.149-160.

Rahman MH. 2015. Character association and genetic diversity of potato (Solanum tuberosum L.). Department of genetics and plant breeding Sher-E-Bangla Agricultural University Dhaka -1207, (MSc. Thesis),Bangladesh.

Robinson HF, Comstock RE, Harvey VH. 1949. Estimates of heritability and degree of dominance in corn. Agron. J., 41: 353-359.

SAS Institute Inc. 2002. Statistical analysis Software version 9.0. Cary, NC: SAS Institute Inc., USA.

Singh BD. 2001. Plant Breeding: Principles and Methods 6th ed. Kalyani Publishers, New Delhi, India.
Singh RK, Chaudhury BD. 1985. Biometrical methods in Quantitative Genetic Analysis. Kalayoni Published, New Delhi, $318 \mathrm{pp}$.

Sivasubramanian S, Menon N. 1973. Heterosis and inbreeding depression in rice. Madras Agricultural Journal, (60): 11391144.

Talburt WF, Smith O. 1959. Potato Processing; Ed. Westport C. T. The Avi Publishing.

Tesfaye A, Yigzaw D. 2008. Review of crop improvement research achievements and future focus in parts of Western Amhara Region: The case of Adet. Tesfaye Abebe, (ed.). In Proceedings of the $1^{\text {st }}$ Amhara Region Regional Workshop on Potato Research and Development Achievements and Transfer Experiences and Future Directions. Bahir Dar, Ethiopia, pp. 85-101.

Tewodros A, Paul C. Struik, Adane H. 2014. Characterization of seed potato (Solanum tuberosum L.) Storage, pre-planting treatment and marketing systems in Ethiopia: The case of West-Arsi Zone. African journal of agricultural research, 9 (15): pp.1218-1226.

Wasu M. 2014. Genetic variability in potato (Solanum tuberosum L.) genotypes for late blight [Phytophthora infestans (Mont.) de Bary] resistance and yield at Haramaya, Eastern Ethiopia. East African Journal of Sciences, 8(1), pp.13-28.

William MA, Woodbury GW. 1968. Specific gravity dry matter relationship and reducing sugar changes affected by potato variety, production area and storage. American Journal of Potato Research, 45 (4): 119-131. 